\title{
The Hand and Environment
}

- Physiological Changes of Skin Temperature, Vibratory Sensibility and Pinch Strength of the Hand and Oxygen Uptake in Two Climatic Conditions-

Katsumi Suzuki ${ }^{1}$, Masateru IjICHI ${ }^{1}$, Takayuki MAtsuki ${ }^{1}$, Akio Seki ${ }^{1}$, Hiromichi TANAKA ${ }^{1}$, Hajime OGATA ${ }^{2}$ and Kageyu NORO ${ }^{3}$

${ }^{1}$ Department of Orthopaedic Surgery, School of Medicine, University of Occupational and Environmental Health, Japan. Kitakyushu 807, Japan

${ }^{2}$ Department of Rehabilitation Medicine, School of Medicine, University of Occupational and Environmental Health, Japan. Kitakyushu 807, Japan

${ }^{3}$ Department of Human Factors Engineering, School of Medicine, University of Occupational and Environmental Health, Japan. Kitakyushu 807, Japan

Abstract: Digital temperatures, pinch strengths, vibratory sensibilities, and oxygen uptakes of 21 healthy male adults in two age groups and under two climatic conditions were studied and compared. 1) The digital temperatures of the older age group were always a little higher than those of the younger age group. 2) Pinch strengths became slightly weakened in the $30^{\circ} \mathrm{C}$ chamber. 3) Vibratory sensibilities at $125 \mathrm{~Hz}$ became slightly sensitive in the $30^{\circ} \mathrm{C}$ chamber. 4) Oxygen uptakes were greater in the $10^{\circ} \mathrm{C}$ chamber.

Key words: digital temperatures, pinch strength, vibratory sensibility, oxygen uptake, age.

(Received 27 January 1981)

\section{Introduction}

Recently, from the standpoint of clinical studies, health control and other medical examinations, there is a tendency for various functions of the hand to be recorded and evaluated by quantitative expressions.

Unfortunately, however, how these normal numerical data change with various environmental and individual conditions has not been clarified to date.

The authors undertook several basic experiments in order to obtain these numerical data. Digital temperature, vibratory sensibility, pinch strength and oxygen uptake, all of which have been utilized clinically by the authors, were selected as the parameters to evaluate the hand function. As environmental conditions, two room temperatures were maintained at different times in a climatic chamber. Data obtained from 21 healthy persons who were examined are reported and discussed in this paper.

\section{Materials and Methods}

A. Twenty-one healthy persons were studied in the experiment, which was undertaken in the winter of 1979. These persons were classified into two age groups, that 
is, an older age group (10 persons older than 38) and a younger age group (11 persons younger than 30 ) (Table 1).

The older age group: Their ages ranged from 38 to 49 (mean: $43.2 \pm 3.4$ years), their body heights from 156 to $175 \mathrm{~cm}$ (mean: $165 \pm 7.1 \mathrm{~cm}$ ) and their body weights from 54 to $85 \mathrm{~kg}$ (mean: 68.4 上 $11.4 \mathrm{~kg}$ ). The younger age group: Their ages ranged from 22 to 30 years (mean: $25.5 \pm 1.7$ years), their body heights from 160.5 to $174 \mathrm{~cm}$ (mean: $168.2 \pm 3.8 \mathrm{~cm}$ ) and their body weights from 50 to $68 \mathrm{~kg}$ (mean: $59.4 \pm 5.7 \mathrm{~kg}$ ). The majority of the 21 persons were right-handed.

Each person to be studied ate a 680-calorie lunch at noon. After evacuating their bladders, they put on 1.8 clo of clothing. Then, at $1.00 \mathrm{pm}$, they entered a climatic chamber, which was kept at $10^{\circ} \mathrm{C}$ and $50 \%$ relative humidity, and sat quietly for 30 minutes.

B. In order to record digital temperatures, tiny thermistors $(0.8 \mathrm{~cm}$ in diameter, manufactured by Nihon Keisokuki Co.) were fixed comfortably on the dorsal surface of the proximal part of the terminal phalanx with adhesive plasters. Digital temperatures were measured only on the middle and ring fingers of both hands and recorded by an electronic automatic balanced recorder (manufactured by Nihon Keisokuki Co., Type EH 300-12).

When 30 minutes had elapsed since the person entered the chamber and digital temperatures were stabilized, the numerical data were measured. Vibratory sensibility was recorded in $\mathrm{dB}$ by stimulating a vibratory sensibility meter (manufactured by Rion Co., Type AU-02) at 125 and $250 \mathrm{~Hz}$ on the pulp of the terminal phalanx of both index fingers. Pinch strength was measured in $\mathrm{kg}$ by a pinch gauge (manufactured by J. A. Preston Co.) between the pulps of the index finger and the thumb, both of which were extended at the interphalangeal joints, of the right and left hands. Expiratory gas was collected into a Douglas bag for 5 minutes and the gas concentration of oxygen was analyzed with a gas analyzer.

C. Then, when the chamber temperature was changed to $30^{\circ} \mathrm{C}$ with the same $50 \%$ relative humidity, the above procedures were repeated.

These data were tabulated as a mean standard deviation and tested by a paired $\mathrm{t}$ test in this paper.

Table 1. Physical characteristics (mean \pm S. D. ) of the subiects

\begin{tabular}{cccc}
\hline Subject group (No. examined) & Age (years) & Height (cm) & Body weight (kg) \\
\hline Older (n:10) & $43.2 \pm 3.4$ & $165.0 \pm 7.1$ & $68.4 \pm 11.4$ \\
Younger (n:11) & $25.5 \pm 1.7$ & $168.2 \pm 3.8$ & $59.4 \pm 4.7$ \\
Paired t test & n.s. & n.s. & $P<0.02$ \\
\hline
\end{tabular}




\section{Result}

A. Experiment at the chamber temperature of $10^{\circ} \mathrm{C}$ (Tables 2, 3, 4, 5, 6 and 7)

The older age group showed skin temperatures of $19.0 \pm 4.1^{\circ} \mathrm{C}$ on the right fingers and $18.4 \pm 3.6^{\circ} \mathrm{C}$ on the left fingers, pinch strengths of $5.4 \pm 0.8 \mathrm{~kg}$ in the right fingers and $5.1 \pm 1.4 \mathrm{~kg}$ in the left fingers, vibration sensibilities of $2.0 \pm 6.4 \mathrm{~dB}$ at $125 \mathrm{~Hz}$ on the right fingers, $-0.25+4.9 \mathrm{~dB}$ at $125 \mathrm{~Hz}$ on the left fingers, $11.75 \pm 6.5 \mathrm{~dB}$ at $250 \mathrm{~Hz}$ on the right fingers and $6.25 \pm 5.7 \mathrm{~dB}$ at $250 \mathrm{~Hz}$ on the left fingers, and oxygen uptake of $4.05 \pm 0.66 \mathrm{ml} / \mathrm{kg} / \mathrm{min}$.

The younger group revealed skin temperatures of $16.3 \pm 2.1^{\circ} \mathrm{C}$ on the right fingers and $15.9 \pm 1.7^{\circ} \mathrm{C}$ on the left fingers, pinch strengths of $5.2 \pm 1.4 \mathrm{~kg}$ in the right fingers and $5.2 \pm 1.3 \mathrm{~kg}$ in the left fingers, vibration sensibilities of $3.64 \pm 9.1 \mathrm{~dB}$ at $125 \mathrm{~Hz}$ on the right fingers, $3.64 \pm 7.3 \mathrm{~dB}$ at $125 \mathrm{~Hz}$ on the left fingers, $14.32 \pm 10.4 \mathrm{~dB}$ at $250 \mathrm{~Hz}$ on the right fingers and $14.09 \pm 11.7 \mathrm{~dB}$ at $250 \mathrm{~Hz}$ on the left fingers, and oxygen uptake of $4.65 \pm 0.51 \mathrm{ml} / \mathrm{kg} / \mathrm{min}$.

B. Experiment at the chamber temperature of $30^{\circ} \mathrm{C}$ (Tables 2, 3, 4, 5, 6 and 7)

The older age group exhibited skin temperatures of $34.0 \pm 1.0^{\circ} \mathrm{C}$ on the right fingers and $33.6 \pm 0.9^{\circ} \mathrm{C}$ on the left fingers, pinch strengths of $4.3 \pm 0.7 \mathrm{~kg}$ in the right fingers and $4.3 \pm 0.8 \mathrm{~kg}$ in the left fingers, vibration sensibilities of $0.5 \pm 5.5 \mathrm{~dB}$ at $125 \mathrm{~Hz}$ on the right fingers, $0 \pm 5.7 \mathrm{~dB}$ at $125 \mathrm{~Hz}$ on the left fingers, $5.0+6.1 \mathrm{~dB}$ at $250 \mathrm{~Hz}$ on the right fingers and $4.5 \pm 5.9 \mathrm{~dB}$ at $250 \mathrm{~Hz}$ on the left fingers, and oxygen uptake of 3.34 上 $0.59 \mathrm{ml} / \mathrm{kg} / \mathrm{min}$.

Table 2. Digital temperatures (means \pm S. D.) at the two experimental temperatures

$\begin{array}{llcc} & & 10^{\circ} \mathrm{C} & 30^{\circ} \mathrm{C} \\ \text { Older } & \text { Right } & 19.0 \pm 4.1 & 34.0 \pm 1.0 \\ & \text { Left } & 18.4 \pm 3.6^{*} & 33.6 \pm 0.9 \\ \text { Younger } & \text { Right } & 16.3 \pm 2.1 & 33.5 \pm 0.3 \\ & \text { Left } & 15.9 \pm 1.7^{*} & 32.4 \pm 0.7 \\ \text { Paired t test } & & *: P<0.05 \text { (only on left side) } & \text { n. s. }\end{array}$

Table 3. Pinch strengths (mean $\mathrm{kg} \pm \mathrm{S}$. D.) at the two room temperatures, experimental temperatures

\begin{tabular}{llccc}
\hline & & $10^{\circ} \mathrm{C}$ & $30^{\circ} \mathrm{C}$ & Paired t test \\
Older & Right & $5.4 \pm 0.8$ & $4.3 \pm 0.7$ & $P<0.02$ \\
& Left & $5.1 \pm 1.4$ & $4.3 \pm 0.8$ & n.s. \\
\multirow{2}{*}{ Younger } & Right & $5.2 \pm 1.4$ & $5.1 \pm 1.1$ & n.s. \\
& Left & $5.2 \pm 1.3$ & $4.9 \pm 0.9$ & n.s. \\
\hline
\end{tabular}


Table 4. Vibration sensibilities (mean $\mathrm{dB}$ at $125 \mathrm{~Hz} \pm \mathrm{S}$. D. ) at the two room temperatures

\begin{tabular}{llrrr} 
& & \multicolumn{1}{c}{$10^{\circ} \mathrm{C}$} & \multicolumn{1}{c}{$30^{\circ} \mathrm{C}$} & Paired t test \\
\hline \multirow{2}{*}{ Older } & Right & $2.0 \pm 6.4$ & $0.5 \pm 5.5$ & n.s. \\
& Left & $-0.25 \pm 4.9$ & $0 \pm 5.7$ & n.s. \\
Younger & Right & $3.64 \pm 9.1$ & $-1.36 \pm 4.2$ & n.s. \\
& Left & $3.64 \pm 7.3$ & $-3.18 \pm 3.6$ & $P<0.01$
\end{tabular}

Table 5. Vibration sensibilities (mean $\mathrm{dB}$ at $250 \mathrm{~Hz} \pm \mathrm{S}$. D. ) at the two room temperatures

\begin{tabular}{|c|c|c|c|c|}
\hline & & $10^{\circ} \mathrm{C}$ & $30^{\circ} \mathrm{C}$ & Paired $t$ test \\
\hline \multirow[t]{2}{*}{ Older } & Right & $11.75 \pm 6.5^{*}$ & $5.0 \pm 6.1$ & $P<0.05$ \\
\hline & Left & $6.25 \pm 5.7^{*}$ & $4.5 \pm 5.9$ & n.s. \\
\hline \multirow[t]{2}{*}{ Younger } & Right & $14.32 \pm 10.4$ & $2.05 \pm 4.4$ & $P<0.01$ \\
\hline & Left & $14.09 \pm 11.7$ & $1.59 \pm 3.7$ & $P<0.01$ \\
\hline Paired t & & $*: P<0.05$ & & n. s. \\
\hline
\end{tabular}

Table 6. Oxygen uptake (mean $\mathrm{ml} / \mathrm{kg} / \mathrm{min} \pm \mathrm{S}$. D.) at the two room temperatures

\begin{tabular}{lccc} 
& $10^{\circ} \mathrm{C}$ & $30^{\circ} \mathrm{C}$ & Paired t test \\
\hline Older & $4.05 \pm 0.66$ & $3.34 \pm 0.59$ & $P<0.02$ \\
Younger & $4.65 \pm 0.51$ & $4.04 \pm 0.32$ & $P<0.01$ \\
Paired t test & $P<0.05$ & $P<0.01$ & \\
\hline
\end{tabular}

Table 7. Digital temperatures (mean ${ }^{\circ} \mathrm{C} \pm$ S. D.) and body weight at two room temperatures

\begin{tabular}{|c|c|c|c|c|}
\hline \multirow[t]{2}{*}{ Body weight } & \multicolumn{2}{|r|}{$10^{\circ} \mathrm{C}$} & \multicolumn{2}{|c|}{$30^{\circ} \mathrm{C}$} \\
\hline & Right & Left & Right & Left \\
\hline $\begin{array}{c}\text { Less than } 60 \mathrm{~kg} \\
(\mathrm{n}: 11)\end{array}$ & $16.3 \pm 1.7$ & $15.9 \pm 1.7$ & $33.6 \pm 1.2$ & $32.5 \pm 1.4$ \\
\hline $\begin{array}{c}\text { More } \operatorname{than}_{(\mathrm{n}: 10)} 61 \mathrm{~kg} \\
\end{array}$ & $19.0 \pm 4.5$ & $18.4 \pm 3.5$ & $33.8 \pm 0.7$ & $33.4 \pm 0.7$ \\
\hline Paired $t$ test & n. s. & $P<0.05$ & n. s. & n. s. \\
\hline
\end{tabular}

The younger age group showed skin temperatures of $33.5 \pm 0.3^{\circ} \mathrm{C}$ on the right fingers and $32.4 \pm 0.7^{\circ} \mathrm{C}$ on the left fingers, pinch strengths of $5.1 \pm 1.1 \mathrm{~kg}$ in the right fingers and $4.9+0.9 \mathrm{~kg}$ in the left fingers, vibration sensibilities of $-1.36+4.2 \mathrm{~dB}$ at $125 \mathrm{~Hz}$ on the right fingers, $-3.18 \pm 3.6 \mathrm{~dB}$ at $125 \mathrm{~Hz}$ on the left fingers, $2.05 \pm 4.4 \mathrm{~dB}$ at 250 $\mathrm{Hz}$ on the right fingers and $1.59 \perp 3.7 \mathrm{~dB}$ at $250 \mathrm{~Hz}$ on the left fingers, and oxygen uptake of $4.04 \div 0.32 \mathrm{ml} / \mathrm{kg} / \mathrm{min}$. 
C. Comparison between two age groups

The older age group was shorter in height and prominently heavier in body weight $(P<0.02)$ than the younger age group.

The digital temperatures of the older age group were always a little warmer than those of the younger age group, especially on the left fingers. And the right fingers were always recorded at higher temperatures than the left ones.

Pinch strengths between the pulps of the index fingers and the thumbs became slightly weakened in the $30^{\circ} \mathrm{C}$ chamber, especially in the right hands of the older age group $(P<0.02)$.

The vibration sensiblity at $125 \mathrm{~Hz}$ became a little sensitive in the $30^{\circ} \mathrm{C}$ chamber, particularly in the left fingers of the younger age group $(P<0.01)$. The vibration sensibility at $250 \mathrm{~Hz}$ was clearly sensitized in the $30^{\circ} \mathrm{C}$ chamber, except for the left fingers of the older age group, and these differences were definite in the younger age group $(P<0.01)$. A strange difference between the right and left fingers was detected in the older age group in the $10^{\circ} \mathrm{C}$ chamber, in which the older age group was the more sensitive. Conversely, in the $30^{\circ} \mathrm{C}$ chamber, the younger age group became clearly sensitive, especially in the right fingers.

The oxygen uptake was higher in the $10^{\circ} \mathrm{C}$ chamber than in the $30^{\circ} \mathrm{C}$ chamber $(P<0.02)$.

\section{Discussion}

The older age group was shorter and significantly heavier than the younger age group. Under the two experimental temperatures, the digital temperatures of the older age group were always higher than those of the younger age group. The mural tension of the digital vessels might be reduced by aging. On the other hand, the digital temperatures in persons who weighed more than $61 \mathrm{~kg}$ were slightly higher than those in subjects who weighed less than $60 \mathrm{~kg}$, especially on the left fingers in the $10^{\circ} \mathrm{C}$ chamber $(P<0.05)$, as shown in Table 7. The right digital temperatures tended to be higher than the left. This might be caused by the fact that the right hands were the dominant ones. Generally, the digital temperatures were clearly warmer than the room temperatures, and the differences between the digital and room temperatures were greater in the $10^{\circ} \mathrm{C}$ chamber than in the $30^{\circ} \mathrm{C}$ chamber.

Pinch strengths seemed to decrease slightly in the $30^{\circ} \mathrm{C}$ chamber. This tendency was more prominent in the older age group. On the other hand, Thorngren \& Werner (1979) reported that grip strength decreases steadily with age. However, this tendency could not be proved in this study.

Vibrations stimulate, first of all, the quickly-adapting mechanoreceptors of the fingers, which are composed of paccinian corpuscles (sensitive at $60-300 \mathrm{~Hz}$ ) and Meissner's corpuscles (sensitive at $2-40 \mathrm{~Hz}$ ) as stated by Ito (1977). In the $10^{\circ} \mathrm{C}$ chamber, the vibration sensibilities seemed to be worsened, especially at $250 \mathrm{~Hz}$, and the older age group was always more sensitive than the younger age group. Conversely, however, in the $30^{\circ} \mathrm{C}$ 
chamber, the younger age group was more sensitive than the older age group. The quickly-adapting mechanoreceptors are connected to the myelinated A fibers, which have a diameter of between 8 and $15 \mu \mathrm{m}$ and a conduction velocity of $40-70 \mathrm{~m} / \mathrm{sec}$ as stated by Demichelis et al. (1979) and Ito (1977). Goodgold \& Eberstein (1977) demonstrated that both motor and sensory conduction velocities may be lowered by $2-2.4 \mathrm{~m} / \mathrm{sec}$ for each $1^{\circ} \mathrm{C}$ drop in temperature. Also, as reported (Dorfman \& Bosley, 1979), in adult humans, peripheral nerve conduction velocity slows with advancing age at the rate of approximately $-0.15 \mathrm{~m} / \mathrm{sec}$ per year for motor fibers, and $-0.16 \mathrm{~m} / \mathrm{sec}$ per year for sensory fibers. A slight reduction in vibration sensation in persons over 30, especially after age 50, has been reported. Omer (1974) reported that these receptor organs vary with age, region of the body and occupation. One-fourth of all the pacinian corpuscles in the body are in the hands. Receptor organs are constantly dying or being destroyed. The best threshold for detecting vibration is oscillatory stimulation at $200-250 \mathrm{~Hz}$.

The oxygen uptake was greater in the $10^{\circ} \mathrm{C}$ chamber than in the $30^{\circ} \mathrm{C}$ chamber in both age groups.

\section{Acknowledgement}

This work was supported by a grant from a project in science of industrisl ecology. The authors gratefully acknowledge the contribution of Prof. Keizo Shiraki, Mr. Koichi Monji, Mr. Hiroshi Takyu, Mr. Kiyoharu Nakashima, Miss Yoshie Yamanaka and Miss Reiko Sekihara who assisted in the preparation of this experiment.

\section{References}

Demichelis, F., Giaretti, W. A., Barberis, M. L. et al. (1979): Biomedical instrumentation for the measurements of skin sensitivity. IEEE Trans. Biomed. Engin., 26: 326-330.

Dorfman, L. J. \& Bosley, T. M. (1979): Age-related changes in peripheral and central nerve conduction in man. Neurology, 29: 38-44.

Goodgold, J. \& Eberstein, A. (1977): Electrodiagnosis of Neuromuscular Diseases. 2nd ed. Williams \& Wilkins, Baltimore. pp. 110-111.

Ito, T. (1977): Surgery of the Peripheral Nerve. 1st ed. Igakushoin, Tokyo. pp. 15-16.

Omer, G. E., Jr. (1974): Sensation and sensibility in the upper extremity. Clin. Orthop. Relat. Res., 104: 30-35.

Thorngren, K. G. \& Werner, C. O. (1979): Normal grip strength. Acta Orthop. Scand., 50: 255259. 
手と環境

一 2 環境条件下での酸素摂取量, 手の指皮温, 振動覚, ピンチ力の生理学的変動一

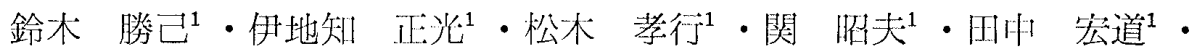

緒方 甫 $^{2}$ ・野吕 影勇 ${ }^{3}$

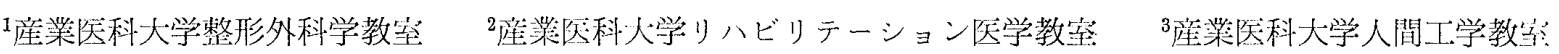

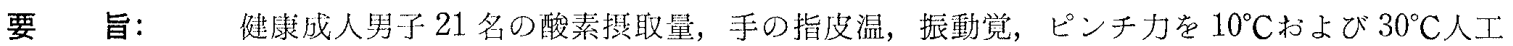
参象室で测定し，高令群と若年群とに分けて，検討した。1）奌命群では，常に指皮温は 若年群より高かった，2）ピンチ力は，30²室内で僅かに低下，3） $125 \mathrm{~Hz}$ 振動觉は，

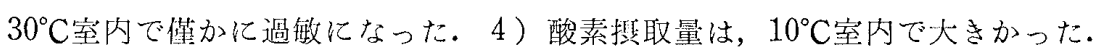

J. UOEH（産業医大誌），3 (2)：109-115 (1981) 